\title{
Conservation Design and Scenario for Flood Mitigation on Arui Watershed, Indonesia
}

\author{
Mahmud $^{1,4}$, Ambar Kusumandari ${ }^{*}$, Sudarmadji ${ }^{3}$ and Nunuk Supriyatno ${ }^{2}$ \\ ${ }^{1}$ Graduated Program of Forest Science, Gadjah Mada University, Yogyakarta, Indonesia \\ ${ }^{2}$ Faculty of Forestry, Gadjah Mada University, Yogyakarta, Indonesia \\ ${ }^{3}$ Faculty of Geography, Gadjah Mada University, Yogyakarta, Indonesia \\ ${ }^{4}$ Faculty of Forestry, Papua University, Manokwari, West Papua, Indonesia
}

Received: 2018-10-21 Accepted: 2019-11-27

\section{Keywords: \\ Design and scenario, conservation, \\ mitigation, \\ Arui watershed}

Correspondent Email: ambarkkusumandari@ugm. ac.id

\begin{abstract}
Flooding has been a natural disaster in Indonesia and elsewhere. This research is designed to create scenarios and designs conservation to mitigate flooding disaster. Data potential, vulnerability, and duplicated river covering $0.25 \%$ of the targeted flooding area were collected and analysed. Five design of conservation, the natural river as control, river normalization, normalization with stone gabion, river straightening, and straightening with gabion stone, and main targeted responses of these five scenarios are river current velocity. Effectiveness scenarios were analysed using Anova and Tukey test. The results showed that straightening with gabion stone was the most effective scenario for flooding mitigation since this was the most effective in increasing river current velocity. This could prevent landslide, accelerate current, overcome flooding, and prevent flooding. Other scenarios such as, normalization stone gabion, deadlock alley ditch, canalization, and riparian reclamation are possible implemented.
\end{abstract}

() 2019 by the authors. This article is an open access article distributed under the terms and conditions of the Creative Commons Attribution(CC BY NC) licensehttps://creativecommons.org/licenses/by-nc/4.0

\section{Introduction}

A watershed destruction is speed up by the utilization of natural resources as impacts of population growth, economic development, conflict of interests, and less inter-sectoral and inter-territorial of uppermiddle-lower intergration, most specifically in the era of regional autonomy (Girolamo and Porto, 2012). Some impacts of watersheds damage such as floods, landslides, drought, and flash flood. Causal factors flood such as damaged water buildings, carrying capasity of river low, changed of rainfall with runoff (Bera and Bhandari, 2013; Hallegatte et al. 2013; Ran and Budic 2016; Worman et al. 2017 Meanwhile, developing countries are particularly vulnerable to flooding impacts because fragile economies (Nammari and Alzaghal, 2015), risk awareness low (Feldman et al., 2016) lack of preparedness and coping capacities (Deen, 2015).

Mahmud et al. (2018) stated that the causes of flood in Arui watershed included as follow: first, a very high rainfall intensity accounted for $718 \mathrm{~mm}$ /day in wet months. Second, meander accounted for 2.01 sinuosity. Third, forest conversion into plantations $(21.46 \%)$. Fourth, $60 \%$ of flat watershed slope $(1-<8 \%)$. Fifth, moderate drainage density. The sixth, oval-shaped watershed of Rc 0.29 and Re 0.289 , and seventh low river gradient of 0.0062 . There are five rivers in the area of Arui watershed. Four upper rivers are located in the southern part. Those are the rivers of Mariam, Macuan, Mantedi, and Nembowi merging into the river of Arui before disembogued at Sarera Kecil Bay. The riverbanks alongside the upper watershed have transformed into palm oil plantations. Forest conversion dominated by palm oil plantations $(21.46 \%)$ in the middle watershed has been the primary cause of the flood. This is due to the fact that no more trees found to protect the river riparian. In addition to those, Widiarto and Kingma (2014) another contributing factor of the flood was a large number of rivers and tributaries.

Disaster management studies of both erosion and flood had been conducted by several researchers. Flood mitigation could be done through the combination of development and evaluation of geographic technology information with integrated spatial planning (Ran and Budic, 2016). Erosion control combination with vegetative and the civil technique (Kusumandari et al. 2013). Stoned and lawned terrace wall conservation techniques were relatively effective to decrease the erosion rate to become below tolerable erosion value (Setiawan, 2012). Despite the research and the efforts, according to Abdulkareem and Elkadi (2018 a new approach for save the urban area that design-based 
like levees, dams, and or channelization. This is so because, as pointed out by Zare and Talebbeydokhti (2018), flood disaster would always be a problem both in dry and rainy seasons even though mitigation and adaptation floods measures are prioritized by disaster planners and policymakers. The implementation of multiple purpose to achieve multiple goals among them groundwater recharge, recreational activities, water supply, flood mitigation, and an restoration of the urban environment (Tingsanchali, 2012).

For this reason, there need to be scenarios and priority designs for flood mitigation, which include normalization, straightening with stone gabion, canalization, deadlock alley ditch, and riparian reclamation with forestry plants and versatile plants. It is expected that these designs will decrease erosion and sedimentation as well as mitigate flood and its impacts.

\section{The Methods}

Geographically, Arui watershed is located at $0^{\circ} 43^{\prime}-0^{\circ} 57^{\prime} \mathrm{S}$ and $133^{\circ} 40^{\prime}-133^{\circ} 48^{\prime} \mathrm{E}$. The total area of Arui watershed covers 23,211,64 hectares (MoLEF,2017). The research was conducted at the Watershed Management Laboratory of the Gadjah Mada Faculty of Forestry, BPDAS \& HL Remu Ransiki and the Arui watershed area in the Regency of Manokwari. The research instruments were a landuse map of 1:100.000 (Figure 1). The data collected from the study location were water, floats, soils, sands, plywoods, stone gabion, and rainfall data from BMG. Instruments used included: measuring instrument, stopwatch, hoe, calculator, computer, and printer. The collected data were both primary and secondary types of data obtained by direct field observation such as river current velocity, sediment, and erosion. Ground water data were obtained from the measurement of community wells in the dry and rainy season (Table 1).

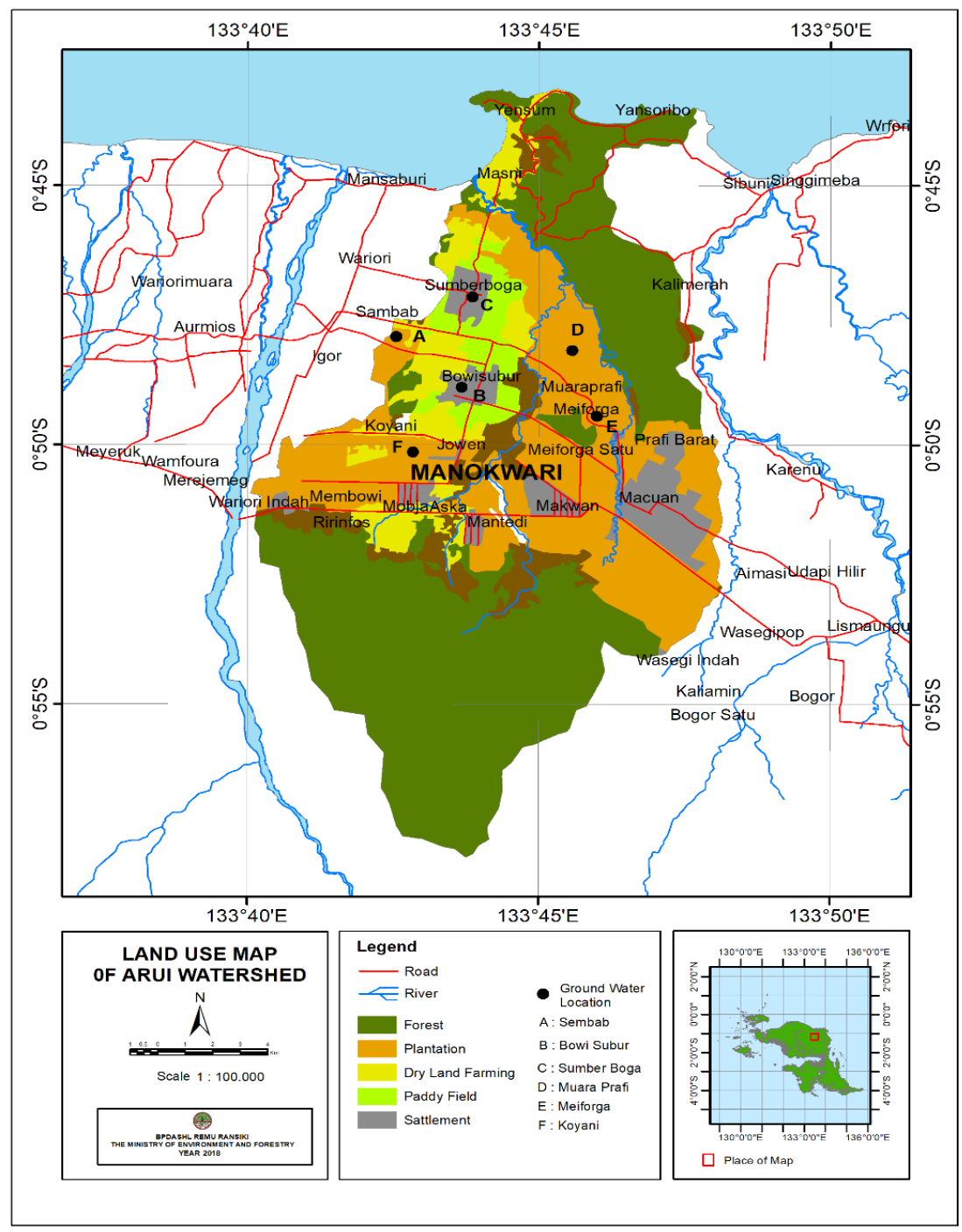

Figure 1. Soil sampling location and Groundwater sampling. 
Table 1. Sediment load, Erosian index and Groundwater.

\begin{tabular}{|c|c|c|}
\hline $\begin{array}{l}\text { SL } \\
\left(\text { ton ha }{ }^{-1} \text { year }^{-1} \text { ) }\right.\end{array}$ & EI & $\mathrm{GW}(\mathrm{m})$ \\
\hline $\mathrm{SL} \leq 5$ (Very low $)$ & $\mathrm{EI} \leq 0.5$ (Very low) & $\mathrm{GW} \leq 5$ (Good) \\
\hline $5<\mathrm{SL} \leq 10$ (Low) & $0.5<\mathrm{IE} \leq 1.0$ (Low) & $5<\mathrm{GW} \leq 10$ (Medium) \\
\hline $10<\mathrm{SL} \leq 15$ (Medium) & $1.0<\mathrm{IE} \leq 1.5$ (Medium) & $\mathrm{GW}>10(\mathrm{Bad})$ \\
\hline $15<\mathrm{MS} \leq 20$ (Height) & $1.5<\mathrm{IE} \leq 2.0$ (Height) & \\
\hline SL > 20 (Very height) & EI>2.0 (Very height) & \\
\hline
\end{tabular}

Note :SL:sediment load (P.61 / Menhut-II /2014); EI: erosian index (P.61 / Menhut-II /2014); GR:groundwater (BP2TP DAS Surakarta,2004)

Conservation design and scenario were based on potentials, characteristics, and the most prioritized threats as well as the possibility for flood mitigation. The scenario and design for Arui watershed flood mitigation began with creating a river duplication measured for $0.25 \%$ of the river where flood occurred. The design covered the natural river, normalization, normalization with gabion stone, stream straightening, and stream straightening with gabion stone. In order to find out the effectiveness of those five designs, current velocity response was taken into consideration. One-way ANOVA and Turkey method was applied to compare the effectiveness of each different treatment on the current velocity. While the DAD simulation begins with determining the infiltration capacity at plantations multiplied land area that can be made DAD divided by the rainfall intensity multiplied by the plantation area, the following DAD simulation:

$$
\mathrm{Sw}=\frac{\mathrm{IC} \times \mathrm{LaD}}{\mathrm{RIn} \times \mathrm{Pa}}
$$

Note: $\mathrm{Sw}=$ Storaged water $(\%)$

IC = Infiltration capasity in plantation $\left(\mathrm{m}_{\text {hour }}^{-1}\right)$

$\mathrm{LaD}=$ The land area is made DAD $\left(\mathrm{m}^{2}\right)$

RIn = Rainfall intensity $\left(\mathrm{m}_{\text {hour }}{ }^{-1}\right)$

$\mathrm{Pa}=$ Plantation area $\left(\mathrm{m}^{2}\right)$

The simulation results are percents of storaged water in the oil palm plantations, while the rest is the amount of runoff. Additionally, literature research was conducted to find out ways for sustainable flood mitigation, such as canalization, and reclamation of river riparian.

\section{Results and Discussion}

\section{Potential and Threats}

The main river of Arui watershed is $25.05 \mathrm{~km}$ long. $60 \%$ of the flat topography is located in the lower areas, $24.62 \%$ of relatively steep topography in the middle areas, and $15.37 \%$ steep topography in the upper areas. Such characteristics allow some potentials include as settlement areas for transmigrants from Java, as plantation areas, and as forests. Another potential include water for both irrigation and water tourism. The dominant type of soil found in Arui watershed is podzolic soil (41\%), characterized by sand clay textures, low $\mathrm{pH}$, and high composition of aluminium and iron. Other characteristics of podzolic soil are poor storability of nutrients, the content of nutrients such as $\mathrm{K}, \mathrm{Ca}$, dan $\mathrm{Mg}$ low, insufficient for annual plants, low level of organic matters, and poor water storage resulting in easy dryness. Physical and chemical properties include dusty clay textures, slow permeability, quite acidic soil $\mathrm{pH}$, available $\mathrm{P}$ from medium to high and available organic matters from low to very low. Currently, Arui Watershed soil has always been wet all year long. This results in poor soil qualities, which in turn affect agriculture practices.

\section{Conservation Design and Scenario}

The integrated combination conservation of the following at the Arui watershed area needs to be taken into consideration: normalization, straightening with gabion stone, canalization, deadlock alley ditch, and riparian reclamation (Figure 2). According to Avinash (2016) the flood as an impact high-intensity rainfall are presently insufficient if only drainage systems improvement.

\section{Normalization}

Nature of normalization is indeed to restore the river into both its initial functions and shapes. Thus, the most important point of normalization is to have river be back into its initial shapes, not to straighten nor concrete its banks as practised these days. Additionally, riverbanks nowadays are prone to development and these practices, in the end, lead to some negative impacts including narrow and shallow river and poor water quality. This means that if normalization is to restore the river's initial functions and shapes, factors contributing to its destruction should then be intervened (Figure 2. normalization area). Similar to Kodoatie and Sugiyanto (2002), river normalization referred to efforts on restoring the river's initial function as water flow container, either through river widening and dredging. 
Table 2. EI values in Arui watershed.

\begin{tabular}{lcccc}
\hline Years & EI & Criteria & Score & Category \\
\hline 2013 & 1.63 & $1.5<\mathrm{EI} \leq 2.0$ & 1.25 & Height \\
2014 & 1.65 & $1.5<\mathrm{EI} \leq 2.0$ & 1.25 & Height \\
2015 & 0.5 & $\mathrm{EI} \leq 0.5$ & 0.5 & Very low \\
2016 & 1 & $0.5<\mathrm{EI} \leq 1.0$ & 1 & low \\
2017 & 10.29 & $2.0<\mathrm{EI}$ & 1.5 & Very height \\
\hline
\end{tabular}

Source: BPDAS \& HL Remu Ransiki (2017)

Table 3. Sediment load in Arui watershed.

\begin{tabular}{lccc}
\hline Years & Sediment load $\left(\right.$ ton ha $^{-1}$ year $\left.^{-1}\right)$ & Clay soil density & Value \\
\hline 2013 & 1.68 & 1.4 & Very low \\
2014 & 2.41 & 1.4 & Very low \\
2015 & 1.32 & 1.4 & Very low \\
2016 & 23.63 & 1.4 & Very high \\
2017 & 23.74 & 1.4 & Very high \\
\hline
\end{tabular}

Source:: BPDAS \& HL Remu Ransiki (2017)

Types of rocks in particular regions will usually determine the types of land shapes there. The land shapes themselves will affect erosion levels, sediments, and river shallowness. Erosion index serves as an indicator of how critical the erosion hazard on particular lands. Table 2 shows that there is an increase in erosion level, categorized from low to very high. The increase in erosion level leads to sediment increase as well, as depicted in Table 3. The sediment load from 2013 to 2017 was accounted between 1,32 to 23,74 ton ha $^{-1}$ year ${ }^{-1}$.

Within the last five years, the highest sediment load was found in 2017 and this showed an upward trend of sediment load ended up in rivers and then on to oceans. This condition had explained why sediments from erosion had been relatively high, even though forests still cover $50 \%$ of the area of Arui watershed. According to Montzka et al. (2008); Dunne et al. (2010) mentioned that well-managed forests will serve such functions to regulate water and to prevent erosion, flood, and landslide. This is so because there is a connection between forests and water availability. Well, preserved forests will result in good river flow capability, both in dry and rainy seasons. In other words, there will be no floods in rainy seasons and no droughts in dry seasons. This is due to the fact that when raining water will infiltrate into the soil to hinder surface streams, hence provide enough water in dry seasons.

The more sediments accommodated in the river bodies will eventually result in fewer areas for the river cross-sections and fewer river capacities. If the river cannot hold water, the water will then find lower areas to inundate and in the end, this can be the main cause of the flood. Those accounted for being sediments can be various; such as litter decomposition, soil particles, and rocks from erosion. Soil particles drift will particularly depend on the condition of the lands. According to Cai et al. (2013), the open and sloping land will be the displaced land particles. A large number of sediments will result in narrow channel, shallowness, and decreased river capacity (Lei et al., 2013). Sediments and water discharges are key benchmarks in analyzing the water supply, to determine the level of availability or volume of water and sediment content in water (Montzka et al., 2008; Mueller et al.,2009).

\section{Straightening with stone gabion}

Naturally, river channels are curvaceous in accordance with the slopes, the altitudes, and with whether there is stream blockage or not. Straightening speeds up water discharge to flow downstream. Stream straightening holds a benefit that if they're to flood in the middle areas of the watershed, the lower areas will not be affected. This is so since the inhabitants are quite a few, so if peak discharge is to cause a flood, no casualties will result. Figure 3 depicts river channel of $410 \mathrm{~m}$ in length with an axis of $203.5 \mathrm{~m}$. The riverbend sinuosity in the flood location known as meandering is 2.01 . 


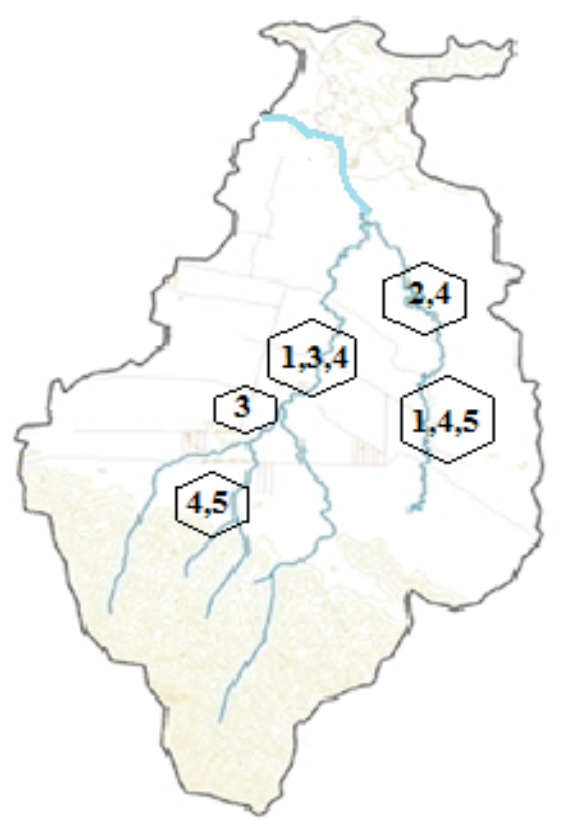

Note: 1. Normalization

2. Straightening with stone gabion

3. Canalization

4. Deadlock alley ditch

5. Riparian reclamation

Figure 2. Sketch of Conservation design and scenario.

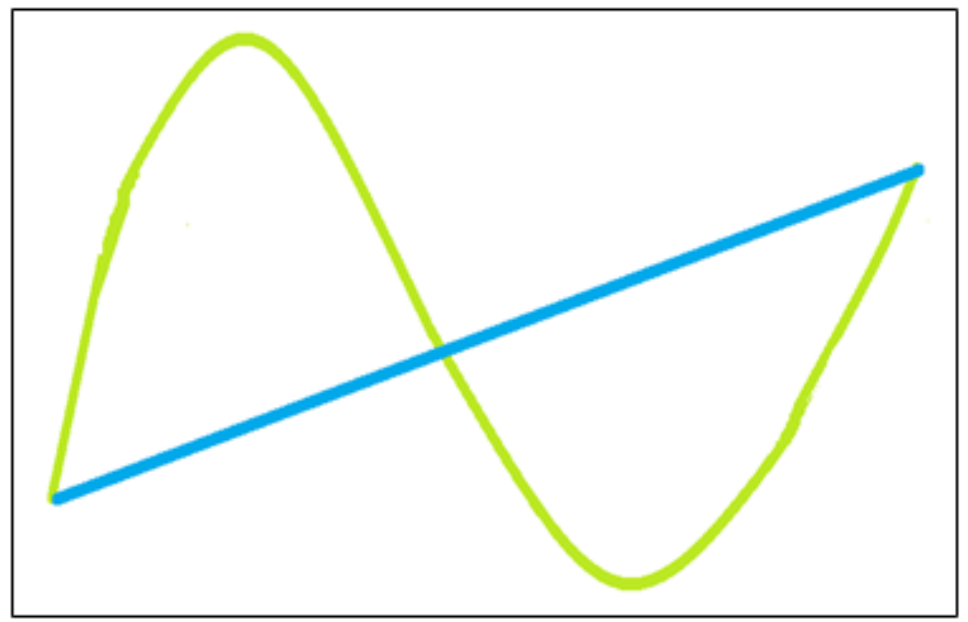

Figure 3. Sketch of Straightening with stone gabion.

Stream straightening of $410 \mathrm{~m}$ long (lime lines indicate stream meandering and blue lines indicate new river ) has been absolutely urgent to be conducted (Figure 3) location of sraightening with stone gabion). This is because rehabilitation and reforestation practices are not the optimum best modes of flood mitigation. The ultimate goal of these rehabilitation and reforestation practices are basically to restore forests by applying some ecological principles. Maryono (2007) specified eco-hydraulics concept as one that is comprised of the ecological elements as well as one developing those ecological aspects for flood mitigation. On the contrary, unadulterated hydraulics will lead to the destruction of the environment in the areas of flood mitigation. If there is a high intensity of rainfall for a few days, even the soil of merely dominant forest land will eventually be saturated. When raining, saturated soil will get into the river. The stream straightening scenarios consist of these following steps. 
a. Staged meander straightening

As stream straightening requires a big budget, the initial stage needs to focus on straightening U-shaped meanders at the flood location. The difference in the measurement result of normal water discharge before and after meandering was estimated as between 0.88 and $1.36 \mathrm{~m}^{3} \mathrm{~s}^{-1}$. Stream straightening is expected to hold water runoff not to be held at meanders, yet to be directly flowing into other river bodies.

b. River channel straightening

This is to be done by digging and filling the land along the river channel for a new river of $410 \mathrm{~m}$ in length. In the long run, this treatment is expected to decrease the water runoff causing flood at the District of Masni. The results of the interviews with the local people found out that the District of Masni was a free flood zone prior to the openings of the plantations and transmigration programs. The commencement of those two programs in the 1980 paved ways for the flood to occur.

c. Moving the affected inhabitants out

Moving the affected inhabitants serves as the last choice in the scenarios. This is intended not only for their own safety but also as precautions from the future flood. There were a total of seven heads of households alongside the Mokwam river, three alongside the Mantedi river, and twenty alongside the Nembowi river. They were moved into a relatively safer area in Sp5 village, which geographically is a flood-free zone and far from rivers.

There had been mitigation with normalization for the river in the middle of the year 2018. However, it was not stone gabion so that the riverbanks gradually slide and granulated materials were brought into the river flow. If not adequately addressed, this can destruct the riverbanks and make even a shallower river. After straightening to prevent soil from normalization to get into the river, stone gabion needs to be constructed in the riverbanks. The most embankment is constructed by piling up concrete however, this particular technique has quite a few disadvantages since it does not allow water to infiltrate among the rocks. In most cases, concrete dams would usually be broken, collapsed, and destroyed if there were swift current, as formerly experienced by concrete embankment in the Arui watershed. Stone gabion, on the other hand allows even excessive water to infiltrate among the rocks. Although swift current may cause the gabion walls to collapse, they will not be destroyed.

\section{Canalization}

Canalization is a way of flood mitigation referring to collector drains. A canal is constructed by dredging the ground to create a river for public water disposal. Its main function is to control water flow from headwaters by regulating incoming water volume and to decrease excess water within the area by channelling it to the river before being disposed to the ocean.

Figure 4 shows the average depth of groundwater is accounted for $0.9 \mathrm{~m}$, categorized as good. The quality of shallow groundwater might be dependent on either the soil or the rock properties. This is so due to the nature of either the soil or the rock to weaken contaminants. Thus, groundwater pollution level will mostly be determined by aquifer position, aquifer physical quantity and types along with the types of soil or rocks in the non-saturated zone, and aquifer stone construction (Brickera et al., 2017). Groundwater refers to either rainwater directly absorbed into the soil (Pambudi et al., 2013), or infiltrated runoff, or water stored in organic waste and eventually absorbed by the soil. Canalization is expected to decrease groundwater content and to gradually improve the soil $\mathrm{pH}$. The soil of the Arui watershed has always been wet throughout the year resulting in poor soil characteristics. Shallow groundwater may serve as either potential or threat to the Arui watershed.

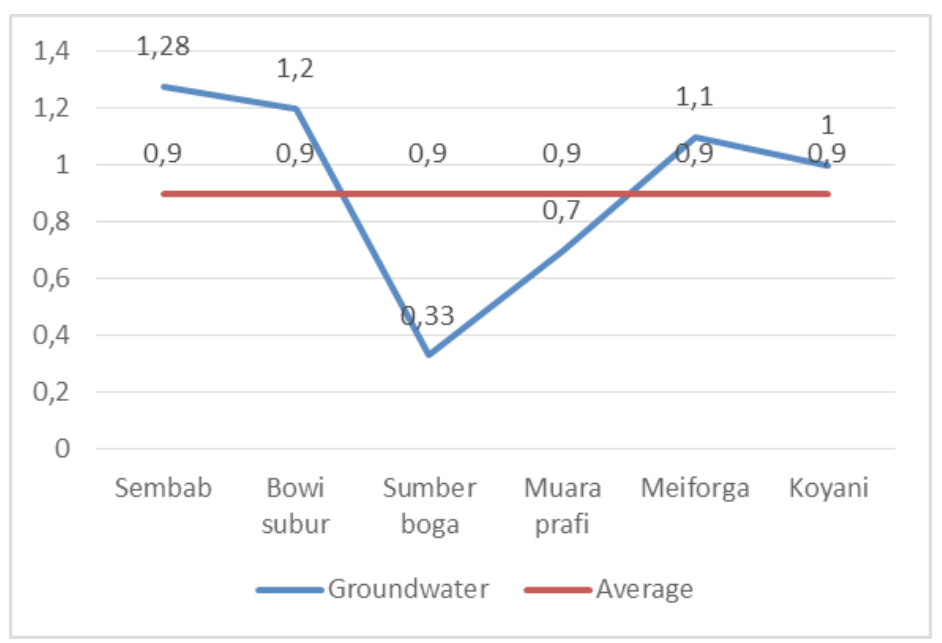

Figure 4. Groundwater depth in Arui watershed. 
The canals were constructed in the villages of Meiforga, Bowi Subur, Sumber Boga and Wariori (Figure 2). Those were 4-8 $\mathrm{m}$ in depth, 0,5-1 $\mathrm{m}$ in slope, and the bottom was $10-12 \mathrm{~m}$ to the river of Maryam. This canalization was expected not only to mitigate flood but also to increase rice productivity in the district of Masni. National standard of Indonesia for rice productivity is 5.1 ton ha ${ }^{-1}$; while it is only 2.5 ton hain the district of Masni. The productivity is lower than that in other regions: West Java 5.37 ton ha $^{-1}$, Central Java 5.34 ton ha ${ }^{-1}$, Yogyakarta 5.28 ton ha ${ }^{-1}$, East Java 5.50 ton ha-1, The Regency of Pesawaran 4.79 ton ha ${ }^{-1}$ and the Regency of Togamus 4.75 ton ha ${ }^{-1}$ (Nadapdap, 2016).

\section{Deadlock Alley Ditch (DAD)}

DAD refers to a U-shaped soil excavation constructed to cut slopes. Its ultimate functions include to store and to infiltrate runoff. DAD is actually a modification from a ditch and a "rorak". The ditch itself is basically an elongated hole channelled to the river to subdue water. It can mostly be found on peatlands planted with palm oil trees. The ditch is usually made along the palm oil plantation and channelled to the rivers. Meanwhile, "rorak" is a wells-like hole serving as water runoff storage. "Rorak" is commonly made with the following measurement: either length 1-2 m, width $0.25-0.50 \mathrm{~m}$ and depth $0.20-0.30 \mathrm{~m}$, or length $1-2$ $\mathrm{m}$, width $0.3-0.4 \mathrm{~m}$ and depth $0.4-0.5 \mathrm{~m}$.

If DAD of $2 \times 1 \times 9 \mathrm{~m}$ with every distance $1 \mathrm{~m}$ (Figure 5), for 1 ha palm oil plantation of $8 \times 9 \mathrm{~m}$ plant spacing, there will be 12 ditches, can hold up to 2160 $\mathrm{m}^{3} \mathrm{ha}^{-1}$. Thus, Pratiwi and Salim (2013) mentioned that the closed space between "rorak" would reduce runoff as well as minimize erosion and the loss of nutrients. The total area of palm oil plantation covers 4,729.81 ha making the water storage capacity of the DAD to be $10,216,390 \mathrm{~m} 3$ equivalent to 30 retention basins of $6 \times 150 \times 400$ m, meanwhile DAD location (Figure 2). Therefore, much water will be retained and stored and this will significantly contribute to flooding mitigation. Risi et al. (2017) described that water catchment area needs to build dams in order to store a large volume of water. Although building dams will contribute a great deal to flood mitigation, it has more limited function as dams merely contain water so that it is not quite favourable for agricultural practices. On the other hand, DAD ditch areas still allow agricultural practices as the ditches are positioned in between plants. If one embung cost about Rp. 50 billion, then for 30 embung is needed about Rp. 1500 billion ( 1.5 trillion).

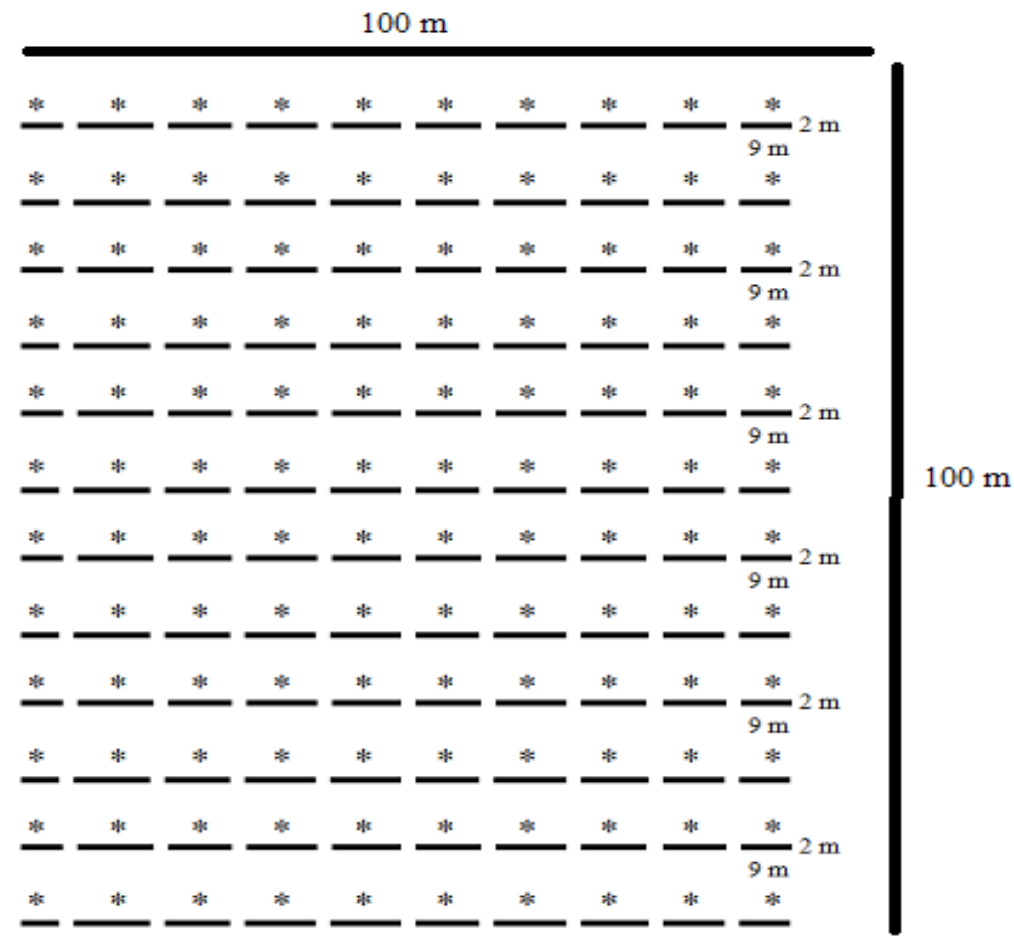

Note: * plant of palm oil plantation DAD of $2 \times 1 \times 9 \mathrm{~m}$

Figure 5. DAD design. 
Table 4. Simulation and water persentage storaged in DAD.

\begin{tabular}{|c|c|c|c|c|c|c|c|}
\hline IC & $\mathrm{LaD}$ & RIn & $\mathrm{Pa}$ & IC x LaD & $\mathrm{RIn} \times \mathrm{Pa}$ & $\begin{array}{c}\text { IC x LaD / } \\
\text { RIn x Pa }\end{array}$ & $\begin{array}{c}\% \\
\text { Storaged water }\end{array}$ \\
\hline & & 0,033 & & & 1537188 & 0,66 & 66 \\
\hline & & 0,086 & & & 4091286 & 0,25 & 25 \\
\hline & & 0,098 & & & 4658863 & 0,22 & 22 \\
\hline 0,0997 & 10216390 & 0,359 & 47298100 & 1018574 & 16980018 & 0,06 & 6 \\
\hline
\end{tabular}

The simulation DAD with rainfall intensity the infiltration capacity of $0.033\left(\mathrm{~m} \mathrm{hour}^{-1}\right)$ then the amount of runoff into the DAD by $66 \%$, while $34 \%$ outside (Table 4). Thus, Pratiwi and Salim (2013) mentioned that the closed space between "rorak" would reduce runoff as well as minimize erosion and the loss of nutrients. While at flooding on February 29, 2016 rainfall of $718 \mathrm{~mm}(0.718 \mathrm{~m})$ infiltration capacity of $0.0997 \mathrm{~m}$ hour $^{-1}$, the amount of surface flow entering in DAD was $6 \%$, while $94 \%$ outside (as run off to enter to rivers, settlements, agriculture)

This water storage system helps to store much more groundwater in the palm oil plantation areas so that very little amount of runoff will flow into the river. Besides, ditch sediments will periodically once every two or three months be reverted into the palm oil trees surroundings. This way the nutrients around the trees will not be carried away to the river but will stay in the ditch. This is in accordance with Pratiwi and Salim (2013) statement that lower rate of erosion, runoff, and nutrient loss will positively affect the plants' growth since such condition willfully accommodate the plants' nutrient and water needs. Conservation techniques on palm oil plantation had been previously practised. According to Satriawan et al. (2017) the particular technique relates to soil conservation with a combination of ground cover plants and dirt. This technique can fairly control both runoff and erosion, in addition to decrease the washing of nutrients. Leafblades gathered and put near deadlock "rorak" will prevent runoff and increase soil fertility, which in turn affecting palm oil plantation soil durability.

Population growth causes not only increased land use, most specifically for settlement and agricultural practices but also increased water needs. Prior to 1980 , the Arui watershed areas were dominated by forests. Yet, at the beginning of 1980 when transmigration program was commenced and transmigrants came from Java, Nusa Tenggara, and Bali, the forest areas had been converted into agricultural lands, palm oil plantation, and settlement areas. The opening of the agricultural land and the palm oil plantation will, later on, contribute a great deal to flooding taken place in the years of 2014,2016, and 2017. This is quite contradictory with the statement of Hartanto and Rachmawati (2017) that basically land conversion does not significantly contribute to flooding.

As Indonesia's second-biggest foreign exchange contributor after the oil and gas industry, the palm oil industry gains special attention from the government. This is because the palm oil industry and its derivatives have played an important role as the source of income for the plantation workers (Satriawan et al., 2017). Even so, palm oil plantation development should indeed not ignore the ecosystems since ignorance might eventually lead to flooding in the future. As discussed by Austin et al. (2017) that recent zero deforestation commitment will help the flood mitigation agenda. Deforestation, in contrast, has a verybig impact on the palm oil plantation, as it is the main cause of flood and drought.

Deforestation was identified as the main cause of flood in the district of Masni in the Regency of Manokwari. The middle areas of the watershed were occupied by the palm oil plantation; while the trees alongside its riverbanks had all been bulldozed. The oil palm plantation covers $4,688.68$ ha in the lower areas and 41.13 ha in the upper areas. Well-maintained deadlock alley ditch can serve several purposes as to hold water, to store water, and to decrease runoff. This means the water will be distributed evenly to the whole areas of the watershed, which in the end will mitigate and prevent the future flood.

\section{River Riparian Reclamation}

Prior to being converted into an palm oil plantation, the riparian of the Arui watershed was occupied by diverse trees. The plantation opening caused all those trees to be bulldozed. The riparian reclamation was expected to restore the functions of the river riparian. Those functions include to decrease the runoff, to hold nutrients, to prevent pollutants from getting into the river, to prevent riverbank avalanches, to repress erosion and sedimentation, to increase the water quality of the river, and to prevent silting of the river. This is accordance with Demsey et al. (2017) riparian zones, forest, and water-related uses are protected, it will improve riparian function. Otherwise according to Gyawali et al. (2013) the land use changes in riparian area to impact on water quality. 
In reclamation important the application of a combination of the vegetative and the civil engineering conservation technique, because of a riparian lot of damage as a result of oil palm plantations and flood 2016. As according to Pratiwi and Salim (2013) mentioned that the application of a combination of the vegetative and the civil engineering conservation technique on a specific location needs to consider such factors as ecological aspects, social community, and types of plants.

River riparian reclamation should be in line with the eco-hydraulics concept (Maryono, 2007), that is, to include and to develop the ecological elements for the flood mitigation. Thus, reclamation here means to restore the functions getting lost in the process of the land opening for the oil palm plantation. In other words, it is to restore the diverse vegetation alongside the riverbanks. This is different from the practice of the Jakarta Bay reclamation whereby the reclamation merely refers to the act of hoarding and piling. The hoarding practice means to alternate the function of the bay/ocean into that of the mainland; therefore, it is not intended to restore the river into its initial function. The function of the ocean is as the border of the mainland and the ocean; it is to hold and to decompose wastes from the mainland as well as to protect the mainland from tsunamis and waves.

\section{Conservation Design Effectiveness}

Five design of conservation such as natural river as control, normalization, normalization with stone gabion, straightening, and straightening with stone gabion. The result of river duplication and conservation design is presented in Table 5.

Table 5. Current velocity river natural and conservation design $\left(\mathrm{m} \mathrm{s}^{-1}\right)$.

\begin{tabular}{ccccc}
\hline SA & $\mathrm{N}$ & $\mathrm{Nbt}$ & $\mathrm{P}$ & $\mathrm{Pbt}$ \\
\hline 0.15 & 0.25 & 0.25 & 0.12 & 0.36 \\
0.21 & 0.16 & 0.25 & 0.47 & 0.38 \\
0.14 & 0.25 & 0.28 & 0.28 & 0.32 \\
0.21 & 0.16 & 0.27 & 0.37 & 0.41 \\
0.22 & 0.26 & 0.28 & 0.29 & 0.39 \\
0.18 & 0.23 & 0.27 & 0.24 & 0.39 \\
0.25 & 0.20 & 0.27 & 0.31 & 0.38 \\
0.20 & 0.24 & 0.28 & 0.28 & 0.40 \\
0.25 & 0.21 & 0.25 & 0.24 & 0.41 \\
0.23 & 0.26 & 0.25 & 0.29 & 0.38 \\
0.18 & 0.23 & 0.24 & 0.28 & 0.30 \\
0.24 & 0.20 & 0.21 & 0.30 & 0.39 \\
0.16 & 0.24 & 0.21 & 0.27 & 0.33 \\
0.22 & 0.16 & 0.22 & 0.36 & 0.36 \\
0.25 & 0.20 & 0.18 & 0.36 & 0.28 \\
\hline
\end{tabular}

Note: SA(natural river); N(Normalization); (Nbt) normalization with stone gabion; $\mathrm{P}$ (straightening); $\mathrm{Pbt}($ straightening with stone gabion)

Analysis of Variance

$\begin{array}{llllll}\text { Source } & \text { DF } & \text { Adj SS } & \text { Adj MS } & \text { F-Value } & \text { P-Value } \\ \text { Conservation } & 4 & 0.2557 & 0.063916 & 29.00 & 0.000 \\ \text { Error } & 70 & 0.1543 & 0.002204 & & \\ \text { Total } & 74 & 0.4099 & & & \end{array}$

Model Summary

$\begin{array}{clll}\text { S } & \text { R-sq } & \text { R-sq(adj) } & \text { R-sq(pred) } \\ 0.0469459 & 62.37 \% & 60.22 \% & 56.80 \%\end{array}$

Means

$\begin{array}{lrlll}\text { Conservation } & \mathrm{N} & \text { Mean } & \text { StDev } & 95 \% \mathrm{CI} \\ \mathrm{P} & 15 & 0.2971 & 0.0760 & (0.2729 ; 0.3213) \\ \mathrm{Pbt} & 15 & 0.3644 & 0.0413 & (0.3402 ; 0.3885) \\ \mathrm{N} & 15 & 0.21711 & 0.03545 & (0.19294 ; 0.24129) \\ \mathrm{Nbt} & 15 & 0.24726 & 0.02988 & (0.22309 ; 0.27144) \\ \mathrm{SA} & 15 & 0.20549 & 0.03725 & (0.18132 ; 0.22967)\end{array}$


Pooled StDev $=0,0469459$

Grouping Information Using the Tukey Method and 95\% Confidence

$\begin{array}{lllc}\text { Konservasi } & \mathrm{N} & \text { Mean } & \text { Grouping } \\ \mathrm{Pbt} & 15 & 0.3644 & \mathrm{~A} \\ \mathrm{P} & 15 & 0.2971 & \mathrm{~B} \\ \mathrm{Nbt} & 15 & 0.24726 & \mathrm{C} \\ \mathrm{N} & 15 & 0.21711 & \mathrm{C} \\ \mathrm{SA} & 15 & 0.20549 & \mathrm{C}\end{array}$

Means that do not share a letter are significantly different.

From the analysis of Anova and Turkey method, it was found that the most effective toward the current velocity was the straightening with gabion stone; while the least effective one was the natural river (without any designs). Stream straightening had several advantages, such as to improve current velocity from upper to lower areas and to prevent runoff. This was in accordance with Kodoatie and Sugiyanto (2002) study describing that straightening was indeed to drain flood discharge faster to the upper, middle, and lower areas. The slow current would result in the water being held and stagnant. If the situation was not addressed, it would cause the flood.

The example on how to implement the design was that of Giriasih Village. The Giriasih community applied the normalization of a water drainage channel that emptied into the rivers of Cibingbin and Cipeusing. This was their way of coping with flood in their village. Normalization of the river functions is urgently needed for the flood mitigation especially in the areas where the rainfall intensity is high. Low river capacity will result in water not being held in the river channels so that it will overflow to inundate the areas of nearby settlement. Normalization will transform the river so that it becomes deeper and wider; therefore, more volumes of water will be stored, which in turn can control the flood threat. According to Widiarto and Kingma (2014) periodic normalization of a river can serve as a strategy to reduce loss as impacts flood.

Normalization without stone gabion was not fairly effective to mitigate flood. From the result of the analysis, the current velocity level for this particular treatment occupied the fourth position, indicating that it was ineffective. This was so since the normalization was only intended to scrape the sediments. The sediments were mostly sandy materials so that those were going to return to the river bodies once the rainfall intensity was high. On the other hand, the straightening using stone gabion was the most effective since this was the most effective to increase the current velocity. This particular type of conservation had been prioritized in the flood-prone zones in the year 2016. Implementing this technique would prevent riverbank avalanches, increase current velocity, mitigate flood, and prevent the future flood.

\section{Conclusion}

The results of the design and the scenario indicated that the most effective flood mitigation was straightening through stone gabion since it was the most effective to increase the current velocity. Thus, applying the technique would help to prevent future flood. Meanwhile, other techniques such as normalization with stone gabion canalization, $\mathrm{DAD}$, and river riparian reclamation would serve as ways of coping with such problems as relatively poor physical and chemical soil properties, slow infiltration, shallow groundwater, increasing sedimentation, and annual rainfall. Stepped stone gabion would prevent sedimentation and riverbank avalanches. DAD could hold water as much as $10,216,390 \mathrm{~m}^{3}$ equivalent to 30 retention basins of $6 \mathrm{x}$ $150 \times 400 \mathrm{~m}$. Usefulness riparian reclamation such as to decrease runoff, to hold nutrients and litters to get into the river, to prevent riverbank avalanches, to control erosion and sedimentation, to increase water quality, and to reduce silting deposition or silting of river.

A pilot project involving civil engineering experts needs to be conducted in order to design a conservation method. In doing so, such factors as types of methods, measurements, funding, and community involvement need to be considered.

\section{Acknowledgement}

This research was funded by LPDP 2016. We thank to Neni, Mr.Batara dewa and Risal. We are extremely grateful to reviewers for useful remarks.

\section{References}

Abdulkareem, M.\& Elkadi, H. (2018). From engineering to evolutionary, an overarching approach in identifying the resilience of urban design to flood. Int. J. Disaster Risk Reduct. 28 176-190. Journal homepage:www. elsevier.com/locate/ijdr

Arsyad, S., (2010). Konservasi Tanah dan Air. Bogor: IPB Press.

Austin, K.G.A., Mosnier, J. Pirker, I. McCallum, S. Fritz, P.S.\& Kasibhatla (2017). Shifting patterns of oil palm driven deforestation in Indonesia and implications for zerodeforestation commitments. Land Use Policy. Journal home page.www.elsevier.com/locate/landuse 
Avinash, S. (2016). Flood related disasters: concerned to urban flooding in Bangalore, India, Int. J. Res. Eng. Technol. 76-83.

Bera, S.\& Bhandari, A (2013). Assessment of flood hazard zone using remote sensing \& GIS - A Case study of Subarnarekha river basin. International Journal of Science and Research (IJSR) 5(9):16071612. ISSN: 23197064.www.ijsr.net

BPDAS \& HL Remu Ransiki, (2017). Laporan Monitoring dan Evaluasi Pengelolaan DAS Arui tahun 2017. Kementerian Lingkungan Hidup dan Kehutanan. Jakarta.

BP2TP DAS Surakarta (2004). Pedoman Monitoring dan Evaluasi Pengelolaan DAS. BP2TP DAS. Surakarta.

Brickera S.H., Banksa V.J., Galikb, G., Tapetea, D.\& Jones, R. (2017). Accounting for groundwater in future city visions. Land Use Policy 89(2017)618-630. Journal home page.www.elsevier.com/locate/ landuse

Cai, T., Li Q., Yu, M., Lu, G., Chen, L.\& Wei, X. (2012). The investigation into the impacts of land-use change on sediment yield characteristics in the upper Huaihe River basin, China. Physics and Chemistry of the Earth journal 5354: 19. https://doi.org/10.1016/j.pce. 2011.08.023.

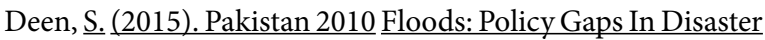
Preparedness and Response. Int. J. Disaster Risk Reduct. 12 341-349 journal homepage www.elsevier. com/locate/ijdr

Demsey, J.A., Plantinga, A.j., Kline, J.D., Lawler J.J., Martinuzzi, S., Radeloff, V.C.\& Bigelow, D.P., (2017). Effects of local land use planning on development and disturbance in riparian areas. Land Use Policy Journal 60:16-25. https://doi.org/10.1016/j.landusepol.2016.10.011.

Dunne, T .,Western, D.\& Dietrich, W.E. (2010). Effects of cattle trampling on vegetation, infiltration and erosion in tropical rangeland. Journal of arid environments 75 (2011058-69

Feldman, D., Contreras, S, Karlin, B., Basolo, V., Matthew, R.,Sanders B.,Houston, D.,Cheung, W.,Goodrich,K.,Reyes,A., Serrano, K.,Schubert,J. \&Luke, A. (2016).Communicating flood risk: looking back and forward at traditional and social media outlets. Int. J. Disaster Risk Reduct. 15 43-51.

Girolamo, A.M.D. \& Porto, A,L.(2012). Land use scenario development as a tool for watershed management within the Rio Mannu Basin. Land Use Policy Journal. (29):691-701. https://10.1016/j.landusepol. 2011.11.005.

Gyawali, S., Techato, K., Yuangyai, C.\& Musikavong, C. (2013). Assessment of the relationship between land uses of riparian zone and water quality of river for sustainable development of river basin, A case study of U-Tapao river basin, Thailand. Environmental Sciences (17) 291 - 297. www.sciencedirect.com

Hallegatte, S., Nicholas, R.\& Morlot, J.C. (2013). Future flood losses in major coastal cities. Nature Climate Change 3: 802-806. https://doi.org/10.1038/nclimate1979.

Hartanto, I.S.\& Rachmawati, R. (2017). Assessing the Spatial-Temporal Land-use Change and Encroachment Activities Due to Flood Hazard in North Coast of Central Java, Indonesia. Indonesian Journal of Geography Vol. 49, No.2, December 2017 (165 - 176) DOI: http://dx.doi. org/10.22146/ijg.28402

Kodoatie, R.J.\& Sugiyanto, (2002). Banjir Beberapa Penyebab dan Metode Pengendaliannya Dalam Perspektif Lingkungan. Pustaka Pelajar. Yogyakarta.
Kusumandari, A.,Widiyatno, Marsono, D. Sabarnurdin, S., Gunawan, T.\& Nugroho, P. (2013). Vegetation clustering in relation to erosion control of Ngrancah sub watershed, Java, Indonesia. Procedia Environmental Sciences Vol 17: 205-210.

Lei, X., Qiao,Z., Ailian,Z. \& Ran H.(2013). Assessment of Flood Catastrophe Risk for Grain Production at The Provencial scale in ChinaBased on the BMM Method. Journal of Integrative Agriculture, 12 December 2013,231002320. DOI:10.1016/S2095-3119(13)60587-0

Mahmud, Kusumandari, A., Sudarmadji \& Supriyatno, N. (2018). A Study of Flood Causal Priority in Arui Watershed, Manokwari Regency, Indonesia. Jurnal Manajemen Hutan Tropika Vol. 24, (2) 81-94, August Scientific Article EISSN: 2089-2063 ISSN: 2087-0469 DOI: $\quad 10.7226 /$ jtfm.24.2.81. http://journal.ipb.ac.id/ index.php/ jmht

Maryono A. (2007). Restorasi Sungai. Yogyakarta. Gadjah Mada University Press

Montzka, C., Morton, C., Kunkel, R., Menz, G., Vereecken, H.\& Wendland, F. (2008). Modelling The Water Balance Of A Mesoscale Catchment Basin Using Remotely Sensed Land Cover Data. Journal of Hydrology Science direct 2008. 553,322-334 journal homepage: www.elsevier.com/locate/jhydrol

Mueller, E.N.P.N., Francke. T., Batalla, R.J.\& Bronstert, A. (2009). Modelling the effects of land-use change on runoff and sediment yield for a mesoscale catchment in the Southern Pyrenees. Catena 79 (3): 288-296. https:// doi.org/10.1016/j.catena.2009.06.007.

Nadapdap, H.J.(2016). Productivity Dynamic of Rice, Corn and Soybean in Jawa, Indonesia. Jurnal Penelitian Pertanian Terapan.Vol 17 (1) :1-10. ISSN 1410-5020

Nammari, F.A.\& Alzaghal, M. (2015).Towards local disaster risk reduction in developing countries: challenges from Jordan. Int. J. Disaster Risk Reduct. Vol 12. 34-41.

Pambudi, S., Isnaniawardhani, V., Winantris \& Sudradjat, A. (2013). Sedimentation Dynamics of the Lower Part of Sentolo Formation at Niten Stream Traverse, Girimulyo, West Progo. International journal of advanced science engineering information technology Vol.9 No.5 ISSN 2088-5334

Permenhut (2014). Permenhut. No. 61/Menhut-II/2014 tentang Pedoman Monitoring dan Evaluasi DAS Indonesia. Pemerintah Republik Indonesia Jakarta.

Pratiwi \& Salim, A.G. (2013). Application of Silt Pit Soil Conservation System on Gmelina (Gmelina arborea Roxb.) Planting in Forest Area in Special Purposes Carita, Banten. Jurnal penelitian hutan dan konservasi alam. Vol. 10 No. 3,Desember : 273-282

Purwati, E., Soewardi, K., Kusumantoro, T., Kartasasmita, M.\& Nurjaya, I.W. (2012). Dampak perubahan kawasan hutan menjadi areal industri batubara terhadap kualitas air di Sepanjang DAS Berau-Kalimantan Timur. Jurnal Penginderaan Jauh 8 (2):60 - 70.

Ran, J.\& Budic, Z.N.(2016). Integrating spatial planning and flood risk management: A new conceptual framework for the spatially integrated policy infrastructure. Computers, Environment and Urban Systems Journal 57:6879. https:// doi.org/10.1016/j.compenvurbsys. 2016.01.08

Risi, R.D., Paola, F.D., Turpie, J.\& Kroeger,T.(2018). Life Cycle Cost and Return on Investment as complementary decision variables for urban flood risk management 
in developing countries. Int. J. Disaster Risk Reduct. (28) 88-106 journal homepage www.elsevier. com/locate/ijdr

Satriawan, H.,Fuady, Z. \& Agusni, (2017). Soil conservation techniques in oil palm cultivation for sustainable agriculture. Jurnal Pengelolaan Sumberdaya Alam dan Lingkungan Vol. 7 No. 2 Agustus: 178-183

Setiawan, M.A., (2012). Manajemen risiko erosi tanah terintegrasi hulu DAS Serayu. Kab. Wonosobo Jawa tengah. Disertasi Doktor ilmu Geografi UGM. Yogyakarta

Tingsanchali, T. (2012). Urban flood disaster management. Procedia engineering. 32(2012)25-37.www. Science Direct.com
Widiarto, L.A. \& Kingma, N.(2014). Agricultural Loss Caused by 2007 Sidoharjo's Flood and it's Household Impact. Indonesian Journal of Geography Vol. 46, No.2, December (156 - 166)

Worman, .A, Lindstrom, G. \& Riml, J. (2017). The power of runoff. Journal of Hydrology. home page:w w w. elsevier.com/locate/jhydro0022-1694/2017 http://dx.doi.org/10.1016/j.jhydrol.2017.03.041

Zare, N.\& Talebbeydokhti, N. (2018). Policies and governance impact maps of floods on metropolitan Shiraz (the first step toward resilience modelling of the city). Int. J. Disaster Risk Reduct. (28) 298-317 journal homepage www.elsevier.com/locate/ijdr 